\title{
Inoperable poorly differentiated SCC to vertex of scalp progressing into sagittal sinus treated with palliative Cemiplimab
}

\author{
Katie Grounds ${ }^{1}$ and Odega Emmanuel ${ }^{2}$ \\ ${ }^{1}$ Neath Port Talbot Local Health Board \\ ${ }^{2}$ Singleton Hospital
}

January 28, 2022

\begin{abstract}
Cutaneous squamous cell carcinoma (cSCC) is the second most common non melanoma skin cancer after Basal cell carcinoma, characterised by the malignant proliferation of epidermal keratinocytes. We report a case of an inoperable cSCC of the scalp extending into the sagittal sinus, now responding well to the monoclonal antibody Cemiplimab.
\end{abstract}

\section{Hosted file}

scc_main_document.pdf available at https://authorea.com/users/457754/articles/554464inoperable-poorly-differentiated-scc-to-vertex-of-scalp-progressing-into-sagittal-sinustreated-with-palliative-cemiplimab

\section{Hosted file}

Figure 1 - scc.docx available at https://authorea.com/users/457754/articles/554464inoperable-poorly-differentiated-scc-to-vertex-of-scalp-progressing-into-sagittal-sinustreated-with-palliative-cemiplimab

\section{Hosted file}

Figure 2 - scc.docx available at https://authorea.com/users/457754/articles/554464inoperable-poorly-differentiated-scc-to-vertex-of-scalp-progressing-into-sagittal-sinustreated-with-palliative-cemiplimab 